\title{
Botanical nano composition with maximum bioavailability for pain management
}

\begin{abstract}
The present patent-pending invention relates to a topical pharmaceutical nano composition (with maximum bioavailability) for pain relief was developed. Random clinical study on 100 volunteers showed very fast and effective relief of all types of pain on all patients of both sexes. For severe cases it was observed pain disappeared in less than 10 minutes. Observed results showed excellent results for all ages with no adverse or side effects.
\end{abstract}

Volume 4 Issue 3 - 2017

\author{
Awad Mansour, I Ammar Mansour2 \\ 'University of Akron, USA \\ ${ }^{2}$ Essraa Hospital, Jordan
}

Correspondence: Awad Mansour, University of Akron, $\mathrm{OH}$, USA, Tel 9622-7278278, Email profmansour@gmail.com

Received: November 03, 2017 | Published: December 18, 2017

\section{Description of the invention}

There are hundreds of millions of people suffer from different types of pain daily and the problem lies in dangerous side effects of pain killers available in the international market. For example we can list some of them:

\section{Side effects of over-the-counter medicines'}
a. Nausea
b. Rash
c. Liver damage (with high doses)

Nonsteroidal anti-inflammatory drugs: These may cause

a. Stomach upset, heartburn, and nausea. Taking the medicine with food may help prevent these problems.

b. Stomach ulcers and kidney problems (with long-term use).

c. Allergic reaction.

d. Increased risk of heart attack and stroke. These risks are greater if the medicine is taken at higher doses or for longer than recommended.

No one younger than 20 should take aspirin. It has been linked to Reye syndrome, a serious illness. Examples of side effects of prescription medicines

\section{Anticonvulsant medicines: These may cause}
a. Dizziness
b. Drowsiness
c. Fatigue
d. Headache
e. Confusion
f. Skin rash

Corticosteroids: These may cause
a. Nausea and vomiting
b. Swelling of hands and feet

c. Increased appetite

d. Increased risk of infection

e. Osteoporosis (with long-term use)

f. Cataracts (with long-term use)

Because of the chance of side effects, doctors usually try to prescribe steroid medicines only for a short time.

Pain Relievers: These may cause

a. Constipation

b. Dizziness, light headedness, or feeling faint

c. Drowsiness

d. Nausea or vomiting

Therefore there is a big need for an effective natural bioactive product to reduce pain with maximum bioavailability. Prof. Awad Mansour, has arrived at a nano natural spray with maximum bioavailability to solve this problem in less than few minutes!!! Dr. Ammar Mansour (MD) at AL-Essra Hospital and Dr. B Khasawneh (MD) at Yarmouk University Clinic tried this cosmetic product on more than 100 volunteers from 15 different countries with excellent results!!! Compositions comprising Jordanian Dead Sea salts, Palestinian botanical extracts, active agents, etc., can be produced and used for the first time in the world in accordance with the present invention that is useful to treat or affect different types of pain. For example, the present invention relates to compositions, preferably for topical or local use, which comprise one or more of the following ingredients, including, but not limited to, Jordanian Dead Sea Salts, Palestinian Thyme Extract, Nano Peppermint Extract. The compositions can produce one or more of the following pharmacological effects, including, but not limited to, antibacterial' antiviral, anti-pain, anti-inflammation, nerve relaxation, etc.

\section{Pain management with a topical alcohol treatment ${ }^{2}$}

Rubbing alcohol, stems from its use in the past as a medicinal rubdown, although this is not as common of an application now. Alcohol is also used as Surface Disinfectant, Antiseptic, Astringent and as Liniment for Muscle Aches for cooling and relaxation. 


\section{Palesinian wild extract of thyme}

An edible medicinal grade that is grown in Jenin area in Palestine and in the Mediterranean. There are a multitude of conditions that extract of thyme treats, but the most famous use is its ability to kill infections in the body. Most organisms cannot survive when exposed to the powerful phenols (carvacrol and thymol) which are the active ingredient in this thyme. These ingredients work well on their own but have an added potency when found together in nature.

\section{Here is a list of the powerful actions of oil of thyme}
a. Potent antioxidant
b. Anti-venom (spiders, scorpions, bees, ants and snakes)
c. Anti-viral
d. Anti-fungal
e. Anti-parasitic
f. Natural anesthetic (pain reducer)
g. Mucolytic (thins mucous)
h. Anti-tussive (decreases cough)
i. Antispasmodic

The anti inflammatory properties of thyme extract inhibit causes of bacteria. ${ }^{3}$

\section{Peppermint extract}

Peppermint is derived from the peppermint plant. Peppermint extract is used for a variety of health conditions and can be taken orally in dietary supplements or topically as a skin cream or ointment. ${ }^{4}$

Medicinal uses of peppermint extract: In dietary supplements, peppermint extract has been tried for a variety of digestive problems including: Irritable bowel syndrome, Indigestion, Heartburn, Nausea, Vomiting, Morning sickness, Cramps of the upper gastrointestinal tract and bile ducts, Diarrhoea, Gas, Colds, Coughs, Inflammation of the mouth and throat, Sinus and respiratory infections, Menstrual problems. Menthol is a well-known anti-pain active ingredient of Peppermint. Which is used for Headache, Muscle pain, Nerve pain, Toothache, Inflammation of the mouth and Joint conditions.

\section{Dead sea nano salts}

Dead Sea Salts are only found in Palestine and Jordan and they are collected from Dead Sea then treated by a nano process. Since ancient times, the waters of the Dead Sea, have been renowned for their therapeutic properties and healing qualities. Because of its dense mineral content, dead sea salt is extremely bitter and isn't edible but it does have incredible beauty benefits for skin, hair and more as you'll find out below! But first, let's look at some of the minerals in dead sea salt and what makes them beneficial for beauty. 5,6

\section{Immunity and beauty-boosting minerals in dead sea salt}

Below is some of the minerals found in Dead Sea salt: Magnesium, Calcium, Sulfur, Bromide, Potassium and Zinc.

\section{Benefits of dead sea salt for skin, hair and more}

\author{
a. Purifies Pores \\ b. Gently Exfoliates Skin
}

c. Enhances Skin Hydration

d. Acne-Buster

e. Reduces Skin Roughness

f. Treats Dandruff

g. Soothes Skin Inflammation

h. Reduces Fine Lines \& Wrinkles

i. Calms Skin Allergies

j. Fights Bad Breath

k. Heals Eczema

1. Promotes Hair Growth

m. Minimizes Large Pores

n. For Wavy Hair

o. Reduces Puffy Skin

p. Psoriasis Relief

q. Calms Itchy Skin

r. Prevent and Exfoliate Ingrown Hairs

s. Erases Stretch Marks

t. Whitens and Brightens Teeth

u. For Strong Healthy and Bright Nails

\section{Nano magnesium chloride}

Magnesium Chloride is very safe, with maximum absorption (bioavailability). Medical doctors say our life depends on magnesium. Magnesium is crucial for bone health, Magnesium deficiency causes heart disease and Kidney disease requires magnesium, Dr. Carolyn Dean, Author; The Miracle of Magnesium, What happens if I don't get enough magnesium? A chronic lack of magnesium in the body yields many consequences - including low energy levels. Symptoms of magnesium deficiency include fatigue, weakness, anxiety, and irritability. In his show Dr. Oz shows without Magnesium no organ will work. 50 percent of sudden heart attacks may be due to magnesium deficiency. Dr. James Piercee, Author of Your nutritional key to cardiovascular wellness. "Once Magnesium falls below a certain level, everything goes.” Dr. Andrea Rosanoff, MD, Author of the Magnesium Factor Book.

\section{Mansour nano magnesium mineral}

Pure Jordanian Magnesium Chloride Hexahydrate -from Dead Sea!! Is a $100 \%$ Bioavailable Absorbable!! And when it is used in a nano form it becomes much more bioavailable. While other magnesium supplements (Tablets, Capsules, Powders \& Flakes) fail to Stack-Up to Mansour nano magnesium mineral. Why our bodies do need nano magnesium:
a. It helps the brain recovery from trauma
b. It reduces chances of heart attack and stroke
c. It raises DHA levels
d. It reduces bad breath and it works as an excellent body deo- dorant 
e. Essential to produce, control, and transport of Insulin and hence

f. It helps for hypo- and hyperglycemia for diabetics

g. It helps to control digestion, and reduces irritable bowel syndrome

h. It reduces calcification

i. It helps Heart's muscules to control valves

j. It helps to reduce adrenal fatigue

$\mathrm{k}$. It helps to balance of potassium, calcium and sodium inside heart muscle cells

1. It helps to control high blood pressure

m.It helps to reduce high cholesterol

n. It reduces lactic acid, and reduces pain

o. It helps in relaxation \& relieves stress and depression

p. It reduces spasms

q. It relaxes blood vessels

r. It helps in softening skin

s. It helps prevent Headaces/Migraines

t. It boosts production of Serotonin - the "feel good" brain chemical

u. It helps in ridding of detoxification of heavy metals

Reasons why mansour nano magnesium mineral is the only one to use:

a. It is $100 \%$ natural and safe since it is extracted from Dead Sea.

b. It is the only nano Mgnesium ingredient in the international market.

c. It is the only Magnesium on earth with complete bioavailability(body absorption).

d. It is $100 \%$ pure with no additives, heavy metals or impurities.

33 Magnesium deficiency symptoms: Magnesium is a mineral responsible for numerous bodily processes. An anti-inflammatory mineral offering protection against illnesses like arthritis and Alzheimer's disease, magnesium has been used to remedy problems like high blood pressure, diabetes, respiratory issues, and much more.

\section{Here are 33 signs of a magnesium deficiency:}

a. Calcium deficiency, Poor heart health \& angina, Heart palpitation, Weakness \& Osteoporosis, Muscle cramps, Fibromyalgia, Alcohol dependence, Anemia, Adrenal fatigue, IBS: Irritable bowel syndrome, GERD: Acid reflux, Poor Digestion, Constipation, Obesity, Tremors, Nausea, Headache \& Migraine, Insomnia, Anxiety, Autism \& ADD, High blood pressure, Type II diabetes, Asthma \& Respiratory issues.

b. Dizziness Fatigue, Potassium deficiency Difficulty swallowing Poor memory, Confusion, Kidney stones, Irritable bladder and Painful menstrual cramps.

\section{Causes of magnesium deficiency}

Prescription drugs; depleted soil, pesticides, gmo's and other toxicities, poor nutrient absorption in the gut, sugar \& alcohol, heavy metals, too much calcium, municipal fluoridated water, and wheat \& grains

Over $85 \%$ of us are already known to be chronically-Magnesium deficient!!!

\section{Therapeutic properties of the dead sea}

Curative properties of salt and mud from the Dead Sea have been subject to much scientific research and observation-based clinical studies. The majority of scientific studies have been conducted directly in the vicinity of the Dead Sea by monitoring treatment of patients that come for therapy to nearby spas and clinics.

\section{Maximum bioavailability}

Nano formulation of Jordanian Dead Sea together with nano herbal extracts showed maximum bioavailability and very fast effect. All patients who used the spray got instant relief of all types of pain. A very strong example Dr. Mawaheb Al-Dolaimi a cancer patient who suffered from hip cancer with very severe pain used morphine for the hip and did fail to reduce her severe pain. When she came to Prof. Mansour Cancer Center at Essra Hospital she started Dea Sea Spray and all pains disappeared instantly!!! Which means the spray was much faster and bioavailable than morphine!!

\section{Summary of the invention}

The present invention relates to a topical pharmaceutical composition for treatment of pain. The composition for treating disorder, preferably formed of nano spray contains Dead Sea salts, thyme extract, peppermint extract and alcohol.

\section{Examples of pre-Cclinical results}

The following results were obtained at the clinic of University of Dr. B Khasawneh. One hundred patients with symptomatic, prolapsed irreducible pain sufferers were treated with nano spray for one day to a week. Some patients with mild pain were faster; it took them 1-3 days only to rid of pain while patients with severe pain it took them 3-7 days for pain relief. Few numbers of severe cases who faced a recurrence after 6-12 months (Table 1).

Table I Effect of Dead Sea Spray on Pain Symptoms

\begin{tabular}{|c|c|c|c|c|c|}
\hline \multirow[t]{2}{*}{ Grade } & \multirow[t]{2}{*}{$\begin{array}{l}\text { No. of } \\
\text { patients }\end{array}$} & \multirow[t]{2}{*}{ Symptoms } & \multirow[t]{2}{*}{$\begin{array}{l}\text { Treatment } \\
\text { time }\end{array}$} & \multicolumn{2}{|c|}{ Case status } \\
\hline & & & & Before & After \\
\hline I & 12 & Neck Pain & I Day & Mild & $\begin{array}{l}\text { Pain } \\
\text { Vanished }\end{array}$ \\
\hline 3 & 20 & Joint Pain & 7 Days & Severe & $\begin{array}{l}\text { Pain } \\
\text { Vanished }\end{array}$ \\
\hline I & 15 & Disc Pain & 2 Days & Mild & $\begin{array}{l}\text { Pain } \\
\text { Vanished }\end{array}$ \\
\hline 2 & 10 & $\begin{array}{l}\text { Swelling \& } \\
\text { Joint Pain }\end{array}$ & 3 Days & Severe & $\begin{array}{l}\text { Pain } \\
\text { Vanished }\end{array}$ \\
\hline I & 8 & $\begin{array}{l}\text { Stiff } \\
\text { Shoulders }\end{array}$ & 2 Days & Mild & $\begin{array}{l}\text { Pain } \\
\text { Vanished }\end{array}$ \\
\hline 3 & 6 & $\begin{array}{l}\text { Fibromyagia } \\
\text { Pain }\end{array}$ & 7 Days & Severe & $\begin{array}{l}\text { Pain } \\
\text { Vanished }\end{array}$ \\
\hline 3 & 14 & Trauma Pain & 3 Days & Severe & $\begin{array}{l}\text { Pain } \\
\text { Vanished }\end{array}$ \\
\hline 3 & 10 & $\begin{array}{l}\text { Diabetic } \\
\text { Foot Pain }\end{array}$ & 7 Days & Severe & $\begin{array}{l}\text { Pain } \\
\text { Vanished }\end{array}$ \\
\hline 4 & 5 & $\begin{array}{l}\text { Rheumatoid } \\
\text { Pain }\end{array}$ & 10 Days & Severe & $\begin{array}{l}\text { Pain } \\
\text { Vanished }\end{array}$ \\
\hline
\end{tabular}




\section{Safety and toxicity study}

Toxicity study performed on mice in the animal house showed that the composition is free of adverse effects especially on liver, kidneys, lipid and other body organs.

\section{Conclusion}

This patented botanical nano spray is expected to help hundreds of millions of pain suffering patients of both sexes worldwide. Double blind is still needed to give more reliable results.

\section{Acknowledgements}

Efforts of Dr. Bassam Khasawneh during the clinical period of this work is highly appreciated.

\section{Conflict of interest}

The author declares no conflict of interest.

\section{References}

1. Pain Management- Side Effects of Pain Medicines. WebMed, USA: New York.

2. Riley JL, King C. Self-report of alcohol use for pain in a multi-ethnic community sample. J Pain. 2009;10(9):944-952.

3. K Elhabazi, A Ouacherif, A Laroubi, et al. Analgesic activity of three thyme species, Thymus satureioides, Thymus maroccanus and Thymus leptobotrys. African Journal of Microbiological Research. 2008;2:262267.

4. Davies SJ, Harding LM, Baranowski AP. Novel Treatment of Postherpetic Neuralgia Using Peppermint Oil. Clin J Pain. 2002;18(3):200-202.

5. Katz U, Shoenfeld Y, Zakin V, et al. Scientific evidence of the therapeutic effects of dead sea treatments: a systematic review. Semin Arthritis Rheum. 2012;42(2):186-200.

6. Cheng JK, Lai YJ, Chen CC, et al. Magnesium chloride and ruthenium red attenuate the antiallodynic effect of intrathecal gabapentin in a rat model of postoperative pain. Anesthesiology. 2003;98(6):1472-1479. 